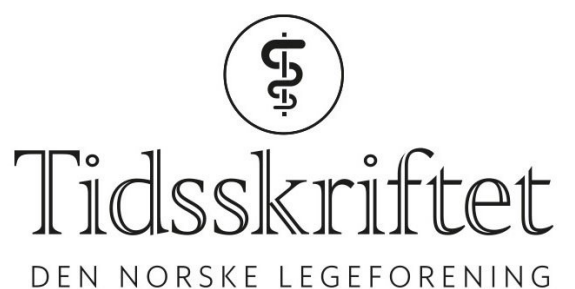

DEN NORSKE LEGEFORENING

\title{
G. Joner svarer
}

KOMMENTAR

\section{GEIR JONER}

E-post: geir.joner@medisin.uio.no

Geir Joner er professor emeritus.

Forfatteren har ikke oppgitt noen interessekonflikter.

Jeg takker Jens Petter Berg og Ivar Prydz Gladhaug for kommentarer til min debattartikkel i Tidsskriftet «Prøveforelesning og morgendagens forskere - nok en gang» $(1,2)$.

Berg og Gladhaug skriver at det er viktig at prøveforelesningens hensikt blir oppfylt. De signaliserer således at de oppfatter dagens praksis med å godkjenne temaer for prøveforelesningen som ligger tett opptil og i noen tilfeller endog overlapper avhandlingens tema kan være problematisk. De drøfter hvordan fakultetet best møter hensikten med prøveforelesningen i dagens ordning, og også prøveforelesningens berettigelse i sitt nåværende format.

Jeg tillater meg å synes at dekanatet underkommuniserer at det er de selv som sitter med nøkkelen til å påvirke praksis så lenge vi har dagens regelverk. Det er jo dekanus som godkjenner bedømmelseskomiteens forslag til tema. Han eller hun har anledning til å ikke godkjenne temaer som ligger for nær avhandlingens tema. Det er uklart for undertegnede hvorfor ikke dekanus benytter denne mulighet ettersom dagens praksis har vært kritisert lenge $(3,4)$ og at dekanatet tidligere har erklært at man bedre praksis $(5)$.

Det problematiseres at prøveforelesninger med temaer langt unna avhandlingen vil skape ekstra utfordringer for bedømmelseskomiteen. Men ettersom prøveforelesningen har som hensikt «å prøve kandidatens evne til å tilegne seg kunnskaper utover avhandlingens tema, og evnen til å formidle disse i en forelesningssituasjon» har jeg vansker med å se at en godt kvalifisert bedømmelsekomite skulle ha vansker med å vurdere kandidatens prestasjon. Og dekanatet skriver jo selv i sin kommentar at «det er mulig å løse dette på en god måte uten at prøveforelesningen foregriper disputasen».

Jeg oppfordrer det medisinske fakultet nok en gang til ikke bare «følge nøye med på at de foreslåtte emnene for prøveforelesningene er bedre i samsvar med instruksene», men faktisk endre praksis.

\section{LITTERATUR:}

1. Berg JP, Gladhaug IP. Viktig at prøveforelesningens hensikt blir oppfylt.

https://tidsskriftet.no/2019/o9/debatt/proveforelesning-og-morgendagens-forskere-nok-en-gang/kom mentarer Lest 25.10.2019.

2. Joner G. Prøveforelesning og morgendagens forskere - nok en gang. Tidsskr Nor Legeforen 2019; 139. 
doi:10.4045/tidsskr.19.0449. [PubMed][CrossRef]

3. Vaglum P. Doktorgradens prøveforelesning har for snevert emnevalg. Tidsskr Nor Legeforen 2013; 133: 1433-4. [PubMed][CrossRef]

4. Gjersvik P. Prøveforelesningens hensikt undergraves - fortsatt. Tidsskr Nor Legeforen 2017; 137. doi: 10.4045/tidsskr.17.0837. [PubMed][CrossRef]

5. Nebb H. Prøveforelesning og morgendagens forskere. Tidsskr Nor Legeforen 2018; 138: 218. [PubMed]

Publisert: 18. november 2019. Tidsskr Nor Legeforen. DOI: 10.4045/tidsskr.19.0689

(C) Tidsskrift for Den norske legeforening 2020. Lastet ned fra tidsskriftet.no 